\title{
Money Management among the Individual Working Personnel in India - A Study with Special Reference to Coimbatore District
}

\section{Dr. Umamaheswari. K \\ Dr. Bhupendra Kumar \\ Mr. Balu J.}

\section{Mr. Birhan Moges Adugna}

Assistant Professor, Lead College of Management, Kerala India

Email ld - uma@lead.ac.in, Mb NO 9159259635

${ }^{1}$ Associate Professor Accounting \& Finance Faculty of Business \& Economics Debre Tabor University Ethiopia email bkradhe@gmail.com Mb - 918058815411

${ }^{1}$ Assistant ProfessorLead College of Management, Kerala India

${ }^{1}$ Department Accounting \& Finance Faculty of Business \& Economics Debre Tabor University Ethiopia Mb- 251918652459E-mail Id -birhanmoges59@gmail.com

\section{Abstract}

Now a day's, money management - financial literacy becomes a foremost challenge faced by most of the developed and developing countries globally. The reviews evidenced that the monetary management level of the individual in India is low. This made the researcher to study the behavioural pattern of the monetary management. As enough research has been carried out by various researchers in this aspect, the researcher considered Coimbatore city which is listed as one of the smart city in India for her study. Coimbatore is known for the place of industrialized, blended of unique culture, no comprehensive study was carried out to study the various aspects of monetary management among the employees.

\section{Key words}

Money management, spending habit, monthly budget, Maintenance of income \& expenditure record, spending pattern

\section{Introduction}

\section{Money management}

Money management is the method of forecasting and tracking the use of capital/money by an individual or group. In the concept of personal finance, the money management comprises budgeting the cost, the spending habit, how they save and investing.

Money management plays an important roleinreducing unnecessaryexpenses which would not increase theworthof aperson's living standards. Proper monetary management willlower the risk on running deficit of money and also allows individuals to attain their long-term financial goals.
Money plays a major role in all of our lives. Now a days many people occupy their energy and time on earning more money.At the same time,it is important to know the art of money spending which helps them to plan, budget and save, promise for long term benefit.So learning about the money management is considered as a foremost steps to achieve the financial goal.

\section{Behavioural aspects taken for this study}

\begin{tabular}{|l|l|}
\hline Money Management & $\begin{array}{l}\text { Preparation of monthly } \\
\text { budget habit, day to day } \\
\text { money management } \\
\text { decisions, Maintenance } \\
\text { of income \& expenditure } \\
\text { record, saving habit, } \\
\text { spending pattern of the } \\
\text { excess money, the mode } \\
\text { of spending pattern after } \\
\text { meeting out all the } \\
\text { expenses. }\end{array}$ \\
\hline
\end{tabular}


Respondents and place of research

The researcher has selected the employees' working in Coimbatore city.

\section{HYPOTHESIS}

Based on the variables selected for this study, the following hypotheses were formulated.

H01: Male and Female respondents do not have an average same opinion on the constructs level of awareness on saving/investment avenues, financial attitude, financial literacy, risk assessment.

H02: Married and unmarried do not have an average same opinion on the constructs level of awareness on saving/investment avenues, financial attitude, financial literacy, risk assessment.

H03: Nuclear and Joint family of the respondents do not have an average same opinion on the constructs level of awareness on saving/investment avenues, financial attitude, financial literacy, risk assessment.

H04: Head and member of the family do not have an average same opinion on the constructs level of awareness on saving/investment avenues, financial attitude, financial literacy, risk assessment.

\section{REVIEWS OF LITERATURE}

Financial literacy is ((Noctor et al. 1992; Australia and New Zealand Banking Group, 2008) defined as 'The ability to make informed judgments and to take effective decisions regarding the use and management of money'. (Huston, 2010) Financial literacy is proficiency in money management, involving both the application of knowledge and the understanding. (GemaZamarro, 2015), the research concludes that food insecurity happens not only due to insufficient income but also because of deficient financial ability.
Households are likely with lower levels of education. Financial literacy is very important for the households to cope up with their limited resources and helps them to manage their money in a better way which guides them to keep away from food insecurity. Heterogeneity occurs if households manage differently with changes in the food price (Caracciolo\&Santeramo, 2013; D’Souza \&Jolliffe, 2012; Santeramo and Khan, 2015).

The global financial literacy (Puneet 2012), survey conducted in many countries shows that due to lack of discussion within the families on the money management results in low financial knowledge within the people. Superior levels of financial literacy are linked with daily financial management skills (Hilgert et al. 2003), retirement planning (Lusardi \& Mitchell, 2007), investments in stocks (Van Rooij, Lusardi, and Alessie, 2011), and wealth accrual (Behrman et al. 2012; Gunderson et al. 2011).

The Joblessness is a strong analyst of food insecurity. But a household that has a higher degree of financial literacy holds savings that protect them from the volatility and food insecurity. It is evident that many of them failed to smooth the consumption throughout the month (Hastings \& Washington 2010), providing extra income would not reduce food insecurity.

The research (Mohamad FazliSabri et al. 2008) concludes that employees are put into financial trouble due to lack of budgeting, poor spending and insufficient idea about money management and it has been suggested that financial education is more important implication at the workplace and Banks, credit unions had more chance to nurture their business. So, they desired to educate the next generation people about the ways to handle money (Closing the Gap, 2008).

Without proper information or guidance (Bodnar, 2005) majority of young adults is required to learn 
how to manage their money and they are not aware of how to balance their cheque books or manage their credit card expenditures.

Nowadays, the entire countries struggle for economic prosperity and it is hard especially for the young people who have never learned how to budget or plan to attain financial security (Kelly, 2002). More women are taught about money management from their parents. Generally, women possess less knowledge on personal finance topics, in spite of proper education and experience which had an impact on the financial literacy of women (Chen, 2002). The global financial literacy, the survey was conducted among 25000 respondents in 28 countries and it was concluded that because of the lack of discussion within the families on money management they have less financial knowledge (Puneet 2012). Superior levels of financial literacy are linked with daily financial management skills (Hilgert et al. 2003), retirement planning (Lusardi \& Mitchell 2007), investments in stocks (Van Rooij et al. 2011), and wealth accrual (Behrman et al. 2012).

\section{METHODOLOGY}

Descriptive research type is chosen for this study and the research data was collected with the use of a questionnaire

\section{Sample size}

The sample size is 536 .

\section{ANAL YSIS FRAMEWORI}

\subsection{Simple Percentage Analysis}

The selected sector respondents are taken for the study based on the demographic factors such as age, gender, the stream of education; income, nature of the job, etc are measured in the analysis.

Percentage analysis $=$ Number of respondents / Total Number of Respondents x 100

\subsection{Z - Test (Test based on Normal Distribution)}

The two groups such as gender and marital status, etc, are compared to their mean values and $\mathrm{Z}$ Test is applied based on the test value of the normal distribution.

\section{OBJECTIVES OF THE STUDY}

1. To assess how money management of individual.

2. To analyse the spending pattern of the excess money, after meeting out all the expenses of the individual.

3. To analyse the level of confidence in managing the financial needs

4. To examine the awareness level of investor on saving/investment avenues.

\section{ANALYSIS AND INTERPRETATION}

\subsection{PERCENTAGE ANALYSIS}

\section{Demographic Profile}

To generalize the opinion given by the respondents on the social, economic and demographic profile, the data are to be analysed on the basis of the respondent's personal profile and to know the personal profile of the respondents under the study; the following frequency distribution is constructed.

Table7.1.1.Demographic Profile of the respondents

\begin{tabular}{|l|c|c|}
\hline Demographic factors & Frequency & Percentage \\
\hline Gender & 315 & 59 \\
\hline Male & 221 & 41 \\
\hline Female & 71 & 13 \\
\hline Age & 130 & 24 \\
\hline Below 25 Years & 154 & 29 \\
\hline 26-35 Years & 116 & 22 \\
\hline 36-45 Years & 65 & 12 \\
\hline 46-55 Years & 56 & 10 \\
\hline Above 56 Years & & 1062 \\
\hline Educational qualification
\end{tabular}




\begin{tabular}{|c|c|c|}
\hline Diploma education & 48 & 9 \\
\hline U.G & 249 & 46 \\
\hline P.G & 113 & 21 \\
\hline $\begin{array}{l}\text { Professional } \\
\text { qualification }\end{array}$ & 70 & 13 \\
\hline \multicolumn{3}{|l|}{ Monthly salary } \\
\hline Below Rs 10000 & 35 & 7 \\
\hline Rs $10001-30000$ & 297 & 55 \\
\hline Rs $30001-50000$ & 148 & 28 \\
\hline Above Rs 50000 & 56 & 10 \\
\hline \multicolumn{3}{|l|}{ Marital Status } \\
\hline Married & 380 & 71 \\
\hline Unmarried & 156 & 29 \\
\hline \multicolumn{3}{|l|}{ Type of family } \\
\hline Nuclear & 143 & 27 \\
\hline Joint & 393 & 73 \\
\hline \multicolumn{3}{|l|}{ Status in the family } \\
\hline Head & 334 & 62 \\
\hline Member & 202 & 38 \\
\hline \multicolumn{3}{|c|}{ Income other than the salary } \\
\hline Yes & 52 & 10 \\
\hline No & 484 & 90 \\
\hline
\end{tabular}

\section{a) Gender}

From the Table 7.1.1.it is found that (59\%) of the respondents are male and $(41 \%)$ of the respondents are female. It is concluded that the majority $(59 \%)$ of the respondents are male.

b) Age

It is found from the Table 7.1.1. that, (13\%) of the respondents are belongs to the age group of below 25 years, $(24 \%)$ of the respondents belongs to the age group between $26-35$ Years, (29\%) of the respondents are belongs to the age group between 36 - 45 Years, (22\%) of the respondents are belongs to the age group between 46-55 Years, (12\%) of the respondents are belongs to the age group of above 56 years. It is concluded that majority (29\%) of the respondents belongs to the age group of 36 - 45 Years.

Educational Qualification

From the Table 7.1.1. it is found that (10\%) of the respondents are having school level education, $(9 \%)$ of the respondents are holding diploma qualification, (46\%) of the respondents are holding U.G degree, $(21 \%)$ of the respondents is PG holders and (13\%) of the respondents belong to Professional educational qualification. It is concluded that the majority $(46 \%)$ of the respondents is Under Graduates.

\section{c) Monthly Salary}

It evident from the Table 7.1.1. that, (7\%) of the respondent's income falls below Rs. 10000 per month, $(55 \%)$ of the respondent's income falls between Rs 10001 - 30000 per month, $(28 \%)$ of the respondent's income falls between Rs 30001 - 50000 per month and $(10 \%)$ of the respondent's income falls above Rs 50000 per month. It is concluded that the majority $(55 \%)$ of the respondent's monthly income falls between Rs 10001 - 30000.

\section{d) Marital Status}

The marital status of the respondents from the Table 7.1.1. implies that (71\%) of the respondents are married and $(29 \%)$ of the respondents are unmarried respectively. It is concluded that the majority $(71 \%)$ of the respondents is married.

e) Type of the Family

It is observed from the Table 7.1.1.that, (27\%) of the respondents are living in the nuclear type of family and $(73 \%)$ of the respondents are living in joint family. It is concluded that the majority $(73 \%)$ of the respondents are living in joint family.

Status in the Family

From the Table 4.1 , it is found that $(62 \%)$ of the respondents are head of the family and $(38 \%)$ of the respondents are a member of the family. It is concluded that the majority (62\%) of the respondents are a head person of their family.

\section{f) Income other than the Salary}

It is found from the Table 7.1.1. (10\%) of the respondents is having other sources of income other than the salary and (90\%) of the respondents do not have other sources of income other than their salary. It is concluded that the majority $(90 \%)$ of the respondents do not have other sources of income other than their salary. 
III. Monetary Management

Table 7.1.2.Monetary Management of the respondents

\begin{tabular}{|c|c|c|}
\hline $\begin{array}{l}\text { Demographic } \\
\text { factors }\end{array}$ & Frequency & Percentage \\
\hline \multicolumn{3}{|c|}{ Preparation of monthly budget habit } \\
\hline Yes & 192 & 36 \\
\hline No & 344 & 64 \\
\hline \multicolumn{3}{|c|}{ If yes, did they stick to it? } \\
\hline Yes & 71 & 13 \\
\hline No & 465 & 87 \\
\hline \multicolumn{3}{|c|}{$\begin{array}{l}\text { Responsible for day-to-day money management } \\
\text { decisions in household }\end{array}$} \\
\hline Self & 158 & 29 \\
\hline Spouse & 124 & 23 \\
\hline Family members & 119 & 22 \\
\hline $\begin{array}{l}\text { You and Your } \\
\text { Spouse }\end{array}$ & 70 & 13 \\
\hline $\begin{array}{l}\text { You and Your } \\
\text { family members }\end{array}$ & 65 & 12 \\
\hline \multicolumn{3}{|c|}{$\begin{array}{l}\text { Maintenance of income } \& \text { expenditure record of the } \\
\text { family }\end{array}$} \\
\hline Yes & 413 & 77 \\
\hline No & 123 & 23 \\
\hline \multicolumn{3}{|c|}{ Monthly income saving habit } \\
\hline $\begin{array}{l}\text { Saving little and } \\
\text { spend more }\end{array}$ & 317 & 59 \\
\hline $\begin{array}{l}\text { Save more and } \\
\text { spend little }\end{array}$ & 219 & 41 \\
\hline \multicolumn{3}{|c|}{$\begin{array}{l}\text { Spending pattern of the excess money, after meetin } \\
\text { out all the expenses }\end{array}$} \\
\hline \multicolumn{3}{|c|}{ Purchase of household articles } \\
\hline Yes & 447 & 83 \\
\hline No & 89 & 17 \\
\hline \multicolumn{3}{|l|}{ Keep it in cash } \\
\hline Yes & 71 & 13 \\
\hline No & 465 & 87 \\
\hline \multicolumn{3}{|c|}{ Invest in capital market } \\
\hline Yes & 20 & 4 \\
\hline No & 516 & 96 \\
\hline
\end{tabular}

\begin{tabular}{|l|c|c|}
\hline Yes & 169 & 32 \\
\hline No & 367 & 68 \\
\hline Invest it in gold and Jewellery \\
\hline Yes & 74 & 14 \\
\hline No & 462 & 86 \\
\hline Paying off loan borrowed \\
\hline Yes & 114 & 21 \\
\hline No & 422 & 79 \\
\hline $\begin{array}{l}\text { Stating the Level } \\
\text { financial needs }\end{array}$ & Confidence in managing the \\
\hline Low & 48 & 9 \\
\hline Neutral & 45 & 8 \\
\hline High & 310 & 58 \\
\hline Very High & 133 & 25 \\
\hline Financial status of previous year \\
\hline \multicolumn{2}{|c|}{} \\
\hline Surplus & 221 & 41 \\
\hline Balanced & 231 & 43 \\
\hline Deficit & 84 & 16 \\
\hline
\end{tabular}

\section{I.Money Management of the respondents: -}

\section{a) Preparation of monthly budget habit: -}

From the Table 7.1.2., It is found that (36\%) of the respondents are preparing a monthly budget and (64\%) of the respondents are not preparing the monthly budget. It is concluded that the majority (64\%) of the respondents are not preparing the monthly budget.

It is observed from the Table (7.1.2.) that, (13\%) of the respondents who prepares the monthly budget are stick to it and (87\%) of the respondents are not stick to their monthly budget plan. It is concluded that the majority $(87 \%)$ of the respondents are not stick to their monthly budget plan.

\section{b) Responsible for day-to-day money management decisions in household: -}

From the Table 7.1.2., it is found that, (29\%) of the respondents are responsible themselves for day-to-day household money management 
decisions, $(23 \%)$ of the respondent's spouse and $(22 \%)$ of the respondent's family members, $(13 \%)$ of the respondents themselves with their spouse and $(12 \%)$ of the respondents themselves with their family members are responsible for their day-to-day household money management decisions. It is concluded that the majority (29\%) of the respondents are responsible themselves for day-to-day household money management decisions.

\section{c)Maintenance of income \& expenditure record of the familly: -}

From the Table 7.1.2. it is observed that (77\%) of the respondent's family is maintaining an income $\&$ expenditure record and (23\%) of the respondent's family does not maintain an income $\&$ expenditure record. It is concluded that the majority $(77 \%)$ of the respondent's family is maintaining an income $\&$ expenditure record.

\section{d) Monthly income saving habit: -}

It is found from the Table 7.1.2. that, about (59\%) of the respondents are belongs to save little and spend more category and $(41 \%)$ of the respondents belongs to the category of Save more and spend little respectively. It is concluded that the majority (59\%) of the respondents belonged to save little and spend more category

\section{II.Spending pattern of the excess money, after meeting out all the expenses}

\section{a) Purchaseof house hold articles: -}

From the Table 7.1.2. It is observed, that (83\%) of the respondents, after meeting out all the expenses they will spend their excess money to purchase the household articles and (17\%) of the respondents do not spend their excess money to purchase the household articles.

\section{b)Keep it in cash: -}

It is found from the Table 7.1.2. that (13\%) of the respondents, after meeting out all the expenses the excess money will keep as cash on their hands and (87\%) of the respondents do not spend their excess money as cash on their hands.

\section{c) Invest in capital market: -}

From the Table 7.1.2. it is observed that only (4\%) of the respondent, after meeting out all the expenses the excess money will be invested in the capital market and $(96 \%)$ of the respondents, the excess money will not be invested in share capital respectively.

\section{d)Lend it to friends or relatives: -}

It is observed from the Table 7.1.2. that, (32\%) of the respondents, after meeting out all the expenses the excess money will be lending to their friends and relatives and (68\%) of the respondents will not lend the excess money to their friends or relatives.

\section{e) Invest it in gold and jewellery: -}

It is found from the Table 7.1.2. that, (14\%) of the respondents, after meeting out all the expenses the excess money will be invested in gold and jewellery and $(86 \%)$ of the respondents will not invest their excess money in gold and jewellery.

\section{f) Paying off loan borrowed: -}

From the Table 7.1.2. it is observed that (21\%) of the respondents are paying off their borrowed loan from the excess money after meeting out all the expenses and $(79 \%)$ of the respondents are not paying off their borrowed loan from the excess money after meeting out all the expenses.

It is concluded from the Table 7.1.2. that the majority $(83 \%)$ of the respondents, after meeting out all the expenses they are spending their excess money to purchase the household articles.

\section{g) Level of confidence in managing the financial needls}

From the Table 7.1.2. It is observed that (9\%) of the respondents are having low level of 
confidence in managing their financial needs, $(8 \%)$ of the respondents are having neutral level, $(58 \%)$ of the respondents are having a high level and $(25 \%)$ of the respondents are having a very high level of confidence in managing their financial needs. It is concluded that the majority (25\%) of the respondents are having a very high level of confidence in managing their financial needs.

It is observed from the Table 7.1.2. that (41\%) of the respondent's financial position in last year was surplus status, (43\%) of the respondents had a balanced financial position and $(16 \%)$ of the respondent's financial position in last year was at deficit status. It is concluded that the majority $(43 \%)$ of the respondents had a balanced financial position in the previous year (2020).

\subsection{Z - TEST (TEST BASED ON NORMAL DISTRIBUTION)}

The two groups such as gender and marital status, etc, are to be compared to their mean values and $\mathrm{Z}$ - Test is applied based on the test value the normal distribution. In this study, based on respondent's gender, marital status, etc. the data is classified into two groups and they are compared on the basis of their mean values, $\mathrm{Z}$ Test is applied.

\subsubsection{Gender on Constructs}

The opinion of the gender on the constructs such as level of awareness on various saving/investment avenues, financial attitude, financial literacy, risk assessment is compared.

H01: Male and Female respondents do not have an average same opinion on the constructs level of awareness on various saving/investment avenues, financial attitude, financial literacy, risk assessment.

H1: Male and Female respondents have an average same opinion on the constructs level of awareness on various saving/investment avenues, financial attitude, financial literacy, and risk assessment.

Table 7.2.1.Z - Test showing constructs compared among gender of the respondents

\begin{tabular}{|c|c|c|c|c|c|}
\hline Constructs & $\begin{array}{c}\text { Gend } \\
\text { er }\end{array}$ & Mean & $|\mathrm{Z}|$ & Sig. & $\begin{array}{c}\text { Remark } \\
\text { s }\end{array}$ \\
\hline \multirow{2}{*}{$\begin{array}{c}\text { Level of } \\
\text { awareness on } \\
\text { various } \\
\text { saving/invest } \\
\text { ment avenues }\end{array}$} & Male & $\begin{array}{c}54.6698 \\
41\end{array}$ & \multirow[b]{2}{*}{0.02} & \multirow[b]{2}{*}{$\begin{array}{c}0.98 \\
4\end{array}$} & \multirow[b]{2}{*}{$\begin{array}{c}\text { Not } \\
\text { Significa } \\
\text { nt }\end{array}$} \\
\hline & $\begin{array}{c}\text { Femal } \\
\mathrm{e}\end{array}$ & $\begin{array}{c}54.6787 \\
33\end{array}$ & & & \\
\hline \multirow[b]{2}{*}{$\begin{array}{l}\text { Financial } \\
\text { attitude }\end{array}$} & Male & $\begin{array}{c}108.463 \\
49\end{array}$ & \multirow[b]{2}{*}{$\begin{array}{c}0.27 \\
3\end{array}$} & \multirow[b]{2}{*}{$\begin{array}{c}0.78 \\
5\end{array}$} & \multirow{2}{*}{$\begin{array}{c}\text { Not } \\
\text { Significa } \\
\text { nt }\end{array}$} \\
\hline & $\begin{array}{l}\text { Femal } \\
\text { e }\end{array}$ & $\begin{array}{c}108.710 \\
41\end{array}$ & & & \\
\hline \multirow[b]{2}{*}{$\begin{array}{c}\text { Financial } \\
\text { literacy }\end{array}$} & Male & $\begin{array}{c}62.5333 \\
33\end{array}$ & \multirow[b]{2}{*}{$\begin{array}{c}0.14 \\
5 \\
\end{array}$} & \multirow[b]{2}{*}{$\begin{array}{c}0.88 \\
4\end{array}$} & \multirow{2}{*}{$\begin{array}{c}\text { Not } \\
\text { Significa } \\
\text { nt }\end{array}$} \\
\hline & $\begin{array}{c}\text { Femal } \\
\mathrm{e}\end{array}$ & $\begin{array}{c}62.4343 \\
89\end{array}$ & & & \\
\hline \multirow[b]{2}{*}{$\begin{array}{c}\text { Risk } \\
\text { assessment }\end{array}$} & Male & $\begin{array}{c}53.5206 \\
35 \\
\end{array}$ & \multirow[b]{2}{*}{$\begin{array}{c}1.03 \\
2\end{array}$} & \multirow[b]{2}{*}{$\begin{array}{c}0.30 \\
3\end{array}$} & \multirow{2}{*}{$\begin{array}{c}\text { Not } \\
\text { Significa } \\
\text { nt }\end{array}$} \\
\hline & $\begin{array}{c}\text { Femal } \\
\mathrm{e}\end{array}$ & $\begin{array}{c}53.1040 \\
72\end{array}$ & & & \\
\hline
\end{tabular}

Note: Significant at 5\% level ( $p$ value $\leq 0.05$, Not Significant at 5\% level ( $\mathrm{p}$ value $>0.05$ )

From the Table 7.2.1. it is understood that for the constructs level of awareness on various saving/investment avenues, financial attitude, financial literacy and risk assessment, the calculated significance values are greater than 0.05 (not Significant) and It is concluded that the opinion between male and female respondents do not differ significantly. Hence null hypothesis is accepted.

\subsubsection{Marital Status on Constructs}

The opinion of the marital status of the respondents on the constructs such as level of awareness on various saving/investment avenues financial attitude, financial literacy, risk assessment is compared.

H02 :Married and unmarried do not have an average same opinion on the constructs level of awareness on various saving/investment avenues, 
financial attitude, financial literacy, risk assessment.

H2 : Married and unmarried have an average same opinion on the constructs level of awareness on various saving/investment avenues, financial attitude, financial literacy, risk assessment.

Table 7.2.2. $\quad Z$ - Test showing constructs compared among Marital Status of the respondents

\begin{tabular}{|c|c|c|c|c|c|}
\hline Constructs & $\begin{array}{l}\text { Marital } \\
\text { Status }\end{array}$ & Mean & $|z|$ & Sig. & Remarks \\
\hline \multirow{2}{*}{$\begin{array}{l}\text { Level of } \\
\text { awareness on } \\
\text { various } \\
\text { saving/investment } \\
\text { avenues }\end{array}$} & Married & 54.3921 & \multirow[b]{2}{*}{2.017} & \multirow[b]{2}{*}{0.044} & \multirow[b]{2}{*}{ Significant } \\
\hline & Unmarried & 55.359 & & & \\
\hline \multirow[b]{2}{*}{ Financial attitude } & Married & 108.3789 & \multirow[b]{2}{*}{0.653} & \multirow[b]{2}{*}{0.514} & \multirow[b]{2}{*}{$\begin{array}{l}\text { Not } \\
\text { Significant }\end{array}$} \\
\hline & Unmarried & 109.0192 & & & \\
\hline \multirow[b]{2}{*}{ Financial literacy } & Married & 62.6368 & \multirow[b]{2}{*}{0.672} & \multirow[b]{2}{*}{0.502} & \multirow[b]{2}{*}{$\begin{array}{l}\text { Not } \\
\text { Significant }\end{array}$} \\
\hline & Unmarried & 62.141 & & & \\
\hline \multirow[b]{2}{*}{ Risk assessment } & Married & 53.3421 & \multirow[b]{2}{*}{0.053} & \multirow[b]{2}{*}{0.958} & \multirow[b]{2}{*}{$\begin{array}{l}\text { Not } \\
\text { Significant }\end{array}$} \\
\hline & Unmarried & 53.3654 & & & \\
\hline
\end{tabular}

Note: Significant at $5 \%$ level ( $p$ value $\leq 0.05$, Not Significant at $5 \%$ level ( $\mathrm{p}$ value $>0.05$ )

From the Table 7.2.2. it is understood that for the constructs financial attitude, financial literacy, and risk assessment, the calculated significance values are greater than 0.05 and It is concluded that opinion between the marital status of the respondents does not differ significantly. Therefore, null hypothesis is accepted.

From the Table 7.2.2. the constructs Level of awareness on various saving/investment avenues (Mean value $=55.3590)$, the Unmarried respondents had a higher opinion than married respondents.

\subsubsection{Type of Family on Constructs}

The opinion of the different type of Family of the respondents on the constructs such as level of awareness on various saving/investment avenues, financial attitude, financial literacy, and risk assessment is compared.

H03 : Nuclear and Joint family of the respondents do not have an average same opinion on the constructs level of awareness on various saving/investment avenues, financial attitude, financial literacy, risk assessment.

H3 : Nuclear and Joint family of the respondents have an average same opinion on the constructs level of awareness on various saving/investment avenues, financial attitude, financial literacy, risk assessment.

\section{Table 7.2.3. $\mathrm{Z}$ - Test showing constructs}

\begin{tabular}{|c|c|c|c|c|c|}
\hline Constructs & $\begin{array}{l}\text { Type } \\
\text { of } \\
\text { Famil } \\
y \\
\end{array}$ & Mean & $|Z|$ & Sig. & $\begin{array}{c}\text { Remark } \\
\text { s }\end{array}$ \\
\hline \multirow{2}{*}{$\begin{array}{l}\text { Level of } \\
\text { awareness on } \\
\text { various } \\
\text { saving/invest } \\
\text { ment avenues }\end{array}$} & $\begin{array}{c}\text { Nucle } \\
\text { ar }\end{array}$ & 55.028 & \multirow[b]{2}{*}{$\begin{array}{c}0.97 \\
9\end{array}$} & \multirow[b]{2}{*}{$\begin{array}{c}0.32 \\
8\end{array}$} & \multirow[b]{2}{*}{$\begin{array}{c}\text { Not } \\
\text { Significa } \\
\text { nt }\end{array}$} \\
\hline & Joint & $\begin{array}{c}54.544 \\
5\end{array}$ & & & \\
\hline \multirow[b]{2}{*}{$\begin{array}{l}\text { Financial } \\
\text { attitude }\end{array}$} & $\begin{array}{c}\text { Nucle } \\
\text { ar }\end{array}$ & $\begin{array}{c}109.81 \\
82\end{array}$ & \multirow[b]{2}{*}{$\begin{array}{c}1.70 \\
1\end{array}$} & \multirow[b]{2}{*}{$\begin{array}{c}0.90 \\
9\end{array}$} & \multirow[t]{2}{*}{$\begin{array}{c}\text { Significa } \\
n t\end{array}$} \\
\hline & Joint & $\begin{array}{c}108.10 \\
94\end{array}$ & & & \\
\hline \multirow[b]{2}{*}{$\begin{array}{l}\text { Financial } \\
\text { literacy }\end{array}$} & $\begin{array}{c}\text { Nucle } \\
\text { ar }\end{array}$ & $\begin{array}{c}63.636 \\
4\end{array}$ & \multirow[b]{2}{*}{$\begin{array}{c}2.06 \\
7\end{array}$} & \multirow[b]{2}{*}{$\begin{array}{c}0.03 \\
9\end{array}$} & \multirow[t]{2}{*}{$\begin{array}{c}\text { Significa } \\
n t\end{array}$} \\
\hline & Joint & $\begin{array}{c}62.076 \\
3\end{array}$ & & & \\
\hline \multirow[b]{2}{*}{$\begin{array}{l}\text { Risk } \\
\text { assessment }\end{array}$} & $\begin{array}{c}\text { Nucle } \\
\text { ar }\end{array}$ & $\begin{array}{c}53.636 \\
4\end{array}$ & \multirow[b]{2}{*}{$\begin{array}{c}0.87 \\
2\end{array}$} & \multirow[b]{2}{*}{$\begin{array}{c}0.38 \\
3\end{array}$} & \multirow{2}{*}{$\begin{array}{c}\text { Not } \\
\text { Significa } \\
\text { nt }\end{array}$} \\
\hline & Joint & $\begin{array}{c}53.244 \\
3\end{array}$ & & & \\
\hline
\end{tabular}

Note: Significant at $5 \%$ level ( $p$ value $\leq 0.05$, Not Significant at $5 \%$ level (p value $>0.05$ )

From the Table 7.2.3. it is understood that the constructs level of awareness on various saving/investment avenues and risk assessment, the calculated significance values is greater than 0.05 , the null hypothesis is accepted. It is 
concluded that the opinion between nuclear and joint family of the respondents do not differ significantly. Therefore, the null hypothesis is accepted.

Hence, from the above constructs financial attitude (Mean value $=109.8182$ ) and financial literacy $($ Mean value $=63.6364)$, the nuclear family had a higher opinion than joint family.

\subsubsection{Status in the Familly}

The opinion of Head and member of the family on the constructs such as level of awareness on various saving/investment avenues, financial attitude, financial literacy, risk assessment is compared.

H04 : Head and member of the family do not have an average same opinion on the constructs level of awareness on various saving/investment avenues, financial attitude, financial literacy, risk assessment.

H4 : Head and member of the family have an average same opinion on the constructs level of awareness on various saving/investment avenues, financial attitude, financial literacy, risk assessment.

Table 7.2.4. $\mathrm{Z}$ - Test showing constructs compared among Status in the Family

\begin{tabular}{|c|c|c|c|c|c|}
\hline $\begin{array}{c}\text { Construc } \\
\text { ts }\end{array}$ & $\begin{array}{l}\text { Status } \\
\text { in the } \\
\text { Family }\end{array}$ & Mean & $|z|$ & Sig. & $\begin{array}{c}\text { Remar } \\
\text { ks }\end{array}$ \\
\hline \multirow{4}{*}{$\begin{array}{l}\text { Level of } \\
\text { awarenes } \\
\text { s on } \\
\text { various } \\
\text { saving/in } \\
\text { vestment } \\
\text { avenues }\end{array}$} & Hond & 54.718 & \multirow{4}{*}{$\begin{array}{l}0.2 \\
65\end{array}$} & \multirow{4}{*}{0.791} & \multirow{4}{*}{$\begin{array}{c}\text { Not } \\
\text { Signific } \\
\text { ant }\end{array}$} \\
\hline & & 0 & & & \\
\hline & Memb & 54.599 & & & \\
\hline & & & & & \\
\hline \multirow{3}{*}{$\begin{array}{l}\text { Financial } \\
\text { attitude }\end{array}$} & Head & 108.53 & \multirow{3}{*}{$\begin{array}{l}0.0 \\
93\end{array}$} & \multirow[t]{3}{*}{0.926} & \multirow{3}{*}{$\begin{array}{c}\text { Not } \\
\text { Signific } \\
\text { ant }\end{array}$} \\
\hline & & 29 & & & \\
\hline & $\begin{array}{c}\text { Memb } \\
\text { er }\end{array}$ & $\begin{array}{c}108.61 \\
88\end{array}$ & & & \\
\hline
\end{tabular}

\begin{tabular}{|c|c|c|c|c|c|}
\hline \multirow{2}{*}{$\begin{array}{c}\text { Financial } \\
\text { literacy }\end{array}$} & Head & $\begin{array}{c}62.565 \\
9\end{array}$ & \multirow[t]{2}{*}{$\begin{array}{l}0.2 \\
81\end{array}$} & \multirow[t]{2}{*}{0.779} & \multirow{2}{*}{$\begin{array}{l}\text { Not } \\
\text { Signific } \\
\text { ant }\end{array}$} \\
\hline & $\begin{array}{l}\text { Memb } \\
\text { er }\end{array}$ & $\begin{array}{c}62.371 \\
3\end{array}$ & & & \\
\hline \multirow{2}{*}{$\begin{array}{c}\text { Risk } \\
\text { assessme } \\
\text { nt }\end{array}$} & Head & $\begin{array}{c}53.509 \\
0\end{array}$ & \multirow[t]{2}{*}{$\begin{array}{l}1.0 \\
36\end{array}$} & \multirow[t]{2}{*}{0.301} & \multirow{2}{*}{$\begin{array}{c}\text { Not } \\
\text { Signific } \\
\text { ant }\end{array}$} \\
\hline & $\begin{array}{l}\text { Memb } \\
\text { er }\end{array}$ & $\begin{array}{c}53.084 \\
2\end{array}$ & & & \\
\hline
\end{tabular}

Note: Significant at 5\% level ( $\mathrm{p}$ value $\leq 0.05$, Not Significant at $5 \%$ level (p value $>0.05)$

From the Table 7.2.4. it is understood that for the constructs level of awareness on various saving/investment avenues, financial attitude, financial literacy and risk assessment, the calculated significance values are greater than 0.05 . It is concluded that the opinion between head and member of the family do not differ significantly. Hence, the null hypothesis is accepted.

\section{FINDINGS OF THE STUDY}

\subsection{Demographic Profille}

a) The majority of the respondents (59\%) are male.

b) The maximum of the respondents (29\%) are in the age group of 36 - 45 Years.

c) The majority of the respondents (46\%) are Under Graduates.

d) The maximum of the respondents (42\%) are working in IT sector.

e) The majority of the respondents (55\%) are having a monthly income between Rs 10001 - 30000.

f) The majority of the respondents (71\%) are married.

g) The maximum of the respondents $(62 \%)$ is ahead person of their family.

h) The maximum of the respondents (90\%) do not have other sources of income other than their salary. 
8.2. Monetary Management

a. The maximum of the respondents (64\%) are not preparing the monthly budget.

b. The majority of the respondents $(87 \%)$ do not stick to their monthly budget plan.

c. The majority of the respondents (29\%) are responsible themselves for day-to-day household money management decisions.

d. The maximum of the respondents' family $(77 \%)$ are maintaining an income \& expenditure record.

e. The maximum of the respondents $(59 \%)$ are belonged to save little and spend more categories.

f. The majority of the respondents (83\%), after meeting out all the expenses they are spending their excess money to purchase the household articles.

g. The maximum of the respondents $(25 \%)$ are having a very high level of Confidence in managing their financial needs.

h. The majority of the respondents (43\%) had a balanced financial position in the previous year.

\subsection{Opinion on the level of awareness on various saving/investment avenues, financial attitude, financial literacy and risk assessment}

a. Z - Test Analysis shows that opinion on the Level of awareness on various saving/investment avenues, financial attitude, financial literacy and risk assessment between male and female respondents do not differ significantly.

b. Z - Test Analysis shows that opinion on the financial attitude; financial literacy and risk assessment between the marital statuses of the respondents do not differ significantly.

c. Z - Test Analysis shows that opinion on level of the financial awareness between the marital statuses of the respondents differs significantly.

d. Z - Test Analysis shows that opinion on the level of awareness on various saving/investment avenues and risk assessment between Nuclear and Joint family do not differ significantly and the opinion on financial attitude, financial literacy between Nuclear and Joint family respondents differs significantly.

e. Z - Test Analysis shows that opinion on the level of awareness on various saving/investment avenues, financial attitude; financial literacy and risk assessment between the Head and Member of family respondents do not differ significantly.

\section{IDISCUSSIONS AND LIMITATIONS}

From the analysis, it is found that the maximum of the respondents does not prepare a monthly budget and Income saving habit is also low as ratified by the research (Mohamad FazliSabri et al. 2008) concluded that employees are put into financial trouble due to lack of budgeting, poor spending and insufficient idea about money management and it was suggested that financial education is more important implication in the workplace. Banks and credit unions had a more chance to nurture their business. So, they desired to educate the next generation that how to handle money (Closing the Gap, 2008) and a survey was conducted in 
different areas such as managing money, planning ahead, making choices and getting help.

The result shows that many people failed to plan in advance and hence they took financial risks without knowing it. Younger people are less financially capable than elders, Financial Service Authority (FSA) (2013).

Nowadays, all countries are struggling for economic prosperity and it is particularly hard for young people, never learned how to budget; plan to attain financial security. (Kelly, 2002). Though, (Duguay, 2001) there was no safety for the young people with inadequate personal savings, most of the young people seen the credit as a source of money and faced a tough situation, which added to their existing debts and ended in bankruptcy court. Most of the students do not have any formal education about money management prior to the graduate from high school. In 2001 Sixteen percent of students (ages sixteen to twenty - two) understood that avoiding money troubles was mostly a matter of fortune. Since personal finance becomes more difficult and people have access to credit at a younger age, it is obvious for them to learn about the techniques to manage one's money that evolves as life skills as reading, writing, and basic math. Thus, the understanding of personal finance helps youth to avoid making privacy mistakes.

This study identified that Level of awareness on various saving/investment avenues of financial products, financial attitude, financial literacy and risk assessment among the gender, age, salary, and respondents belong to the different sector is not similar. It is known from the study, Bhushan\&YajuluMedury (2013) the result suggested that the level of financial literacy diverges radically from respondents based on various demographics and socioeconomic factors and also gets affected by their gender, education qualification, income level, the nature of employment and place of work.
Pallavi Seth et al. (2010) financial literacy is influenced by educational level, age, and income. High-income respondents hold high financial literacy than lower income respondents. (Finke \& Huston 2003) Gender difference in financial attitudes, higher levels of willingness to take the financial risk was associated with higher net worth for both genders. Unsurprisingly, a higher level of education is usually associated with a better understanding of credit reports and credit scores (Lyons et al. 2007) and a higher degree of financial knowledge in general (Bernheim, 1998; Meier and Sprenger, 2008). In addition to formal education, individual cognitive abilities also play an important role. Delavande et al. (2008) estimate a model where the financial knowledge score depends on the cognitive ability and other controls. As expected, ability increases the accuracy of responses to financial tests, because of the education. People developed their own attitudes by observing significant people attitudes in their lives (Bandura, 1977). Hence, there was a difference in financial attitudes by gender, related to gendered financial socialization.

\section{CONCLUSION}

From the analysis, it can be concluded that the overall financial literacy level of the respondents is low. While collecting the questionnaire from the respondent, the respondent felt that they were failing to update the knowledge about various saving/investment avenues and they are in need of training or awareness programs to convert their earnings into worthy. Most of the people are not maintaining the monthly budget; not recording their cash flow and results in lack of confidence in managing their financial needs. The individual does not have sufficient knowledge about the various types of financial product. Hence, only good knowledge and better financial planning will lead to choose a better investment plan. This can be done by providing a strong financial education in secondary and higher secondary levels of the 
education system which shows a foothold on an effective progression.

\section{REFERENCES}

1. Bandgar, PK 1999, 'A Study of MiddleClass Investors' Preferences for Financial Instruments in Greater Bombay', Finance India, vol. XIV, no. 2, pp. 574-576

2. Behrman, Jere, Olivia S Mitchell, Cindy Soo \& David Bravo 2012, Financial Literacy, Schooling, and Wealth Accumulation', American Economic Review, vol. 102, no. 3, pp. pp. 300-304.

3. Bhushan, P \&Medury, Y 2013, 'Gender differences in investment behaviour among employees. Asian Journal of Research in Business Economics and Management. vol. 3, no. 12, pp. 147-157.

4. Caracciolo, F \&Santeramo, FG 2013, 'Price Trends and Income Inequalities: Will SubSaharan Africa Reduce the Gap', African Development Review, vol. 25, no. 1, pp. 42-54.

5. D'Souza, A \& Jolliffe, D 2012, 'Rising food prices and coping strategies: Household-level evidence from Afghanistan'. Journal of Development Studies, vol. 48, no. 2, pp. 282-299.

6. Duguay, D 2001, 'Please Send Money: A Financial Survival Guide for Young Adults on Their Own, Sourcebooks', Naperville, IL.

7. Duguay, D 2001, 'Please Send Money: a Financial Survival Guide for Young Adults On Their Own, Sourcebooks', Naperville, IL.

8. Finke, MS \& Huston, SJ 2003, 'The brighter side of financial risk: Financial risk tolerance and wealth. Journal of Family and Economic Issues, vol. 24, no. 3, pp. 233-256.

9. FSA, 2013, Financial capability in the UK: Delivering change. Financial Services
Authority, UK. Downloaded GemaZamarro 2015, 'Does Financial Literacy Contribute to Food Security', International Journal of Food and Agricultural Economics, vol. 4, no. 1, Special Issue, pp. 1-19.

10. Gundersen, C, Kreider, B \& Pepper, J 2011, 'The Economics of Food Insecurity in the United States Applied Economics Perspectives and Policy', vol. 33, no. 3, pp. 281-303.

11. Hastings, J \& Washington, E 2010, 'The First of the Month Effect: Consumer Behaviour and Store Responses'. American Economic Journal: Economic Policy, vol. 2, no. 2, pp. 142-62.

12. Hilgert, MA, Hogarth, JM \& Beverly, SG 2003, 'Household Financial Management: The Connection between Knowledge and Behaviour', Federal Reserve Bulletin, vol. 89, no. 7, pp. 309-322.

13. Huston, SJ 2010, 'Measuring Financial Literacy Journal of Consumer Affairs Special Issue', Financial Literacy, vol. 44, issue. 2, pp. 296-316.

14. Kelly, C 2002, 'Financial Literacy in Schools. CUNA's Commitment to Providing Financial Education to America's Youth'.

15. Kelly, C 2002, 'Financial Literacy in Schools. CUNA's Commitment to Providing Financial Education to America's Youth'.

16. Lusardi, Annamaria \& Olivia S Mitchell 2007, 'Baby Boomers' Retirement Security: The Role of Planning, Financial Literacy and Housing Wealth, Journal of Monetary Economics', vol. 54, no. 1, pp. 205-224.

17. Lyons, AC, Rachlis, M \&Scherpf, E 2007, 'What's in a score? Diff er-ences in consumers' credit knowledge using OLS and quantile regressions. Journal of 
Consumer Aairs, vol. 41, no. 2, pp. 223249.Bernheim, DD 1998, 'Financial illiteracy, education, and retirement saving'. In Mitchell, OS \&Schieber, SJ (Eds.), Living with Defined Contribution Pensions, The Pension Research Council, Wharton School Pension Research Council, University of Pennsylvania, pp. 38-68.

18. Meier, S \& Sprenger, C 2008, 'Discounting financial literacy: Time preferences and participation in financial education programs. IZA Discussion Paper (No. 3507).Delavande, AS, Rohwedder\& Willis, RJ 2008, 'Preparation for retirement, financial literacy, and cognitive resources. Michigan Retirement Research Center Working Paper No. 2008-190.
19. Mohamad FazliSabri, JariahMasud, Karen Kah Lin \&LailyPaim 2008, 'Personal Financial Wellness among Malaysian Employees: Socio-Demographic Comparison', vol. 54, pp. $189-192$.

20. Pallavi Seth, Patel, GN \& Krishnan, KK 2010, 'Financial Literacy \& Investment Decisions of Indian Investors', A Case of Delhi \& NCR

21. Santeramo, FG \& Khan, N 2015, 'The income-elasticity of calories, macro and micro nutrients: What is the literature telling us', Food Research International FSA.

22. Van Rooij, Maarten, Annamaria Lusardi \& Rob Alessie 2011, 'Financial Literacy and Stock Market Participation', Journal of Financial Economics, vol. 101, no. 2, pp. 449-472. 